\title{
DEMOCRATIC CAPITALIZATION, LOCAL ACTORS, AND POLITICAL PATRONAGE NETWORKS
}

\author{
M. Uhaib As'ad \\ FISIP, Universitas Islam Kalimantan MAB (UNISKA) Banjarmasin \\ Email: uhaibm@yahoo.com
}

\begin{abstract}
This paper explains the conspiracy and involvement boss mine (coal) in several provincial elections (regents and governors) in South Kalimantan. As is known, the political landscape of post Soeharto New Order government that gave birth to democracy and radical change in the institutions of power, namely from the centralized power-authoritarian system to a democratic system of government has spawned a democratic transition which was prolonged until today. In the midst of a prolonged transition to democracy at this time, the arena of democracy has been hijacked and the stage of political and economic power has been controlled by entrepreneurs or local and national capitalist power by doing pesekongkolan between candidates authorities or local authorities that one of them through the local election process. The businessmen are involved as a supplier of funds to the local authorities candidate to win as a form of money politics and transactional politics. In some cases the local elections in South Kalimantan, such as the election of the regent and the governor, political practice is utilized with clarity and has already become a political culture that is structured within massive post-New Order government. Therefore, democracy is being woken up in Indonesia after the New Order.
\end{abstract}

Keywords: local election, local actors, politict-business networks, collaboration.

\section{INTRODUCTION}

Historically, the study of the relationship between state and capital in thehistory of political power in Indonesia, especially under Suharto's government era is a reality of conspiracy between the state capital during past 32 years. The reality of this conspiracy is established through the use of a mutually beneficial institution of power, regulation, and patronage relations to dominate economic resources and political power. Under the Suharto's government era with the political authoritarian power structure the economic resources and political power are in the hands of actor groups who have patronage relationships with those within the bureaucracy of government to accumulation and monopoly of economic resources who have economic and political patronage relationships within the government bureaucracy network.

The rise of Suharto's cronies behavior by Kunio (1991), is described as an erzast capitalism,. Hadiz, (2004), and Winters (2011) called it oligarchy- predatory who were born to obtain facilities and protection from the authorities. Entrepreneurs appear as strategic groups that can influence state policy through conspiracy, which places institutions of power and regulation that are engineered in such a way as to legally control state's economic resources.

The fall of the Suharto's government in May 1998 that led to the transition of democracy has changed the current political order. Although the formal regime had collapsed but the heritage disease grew at the local government, such as the practice of political corruption and nepotism. The political actors who occupy the current stage of power have not undergone much change from the mental oligarch-predatory. The oligarchs are increasingly finding their habitat at the local level with decentralization and local autonomy era to be as an opportunity for these local oligarchs.

In the democratization, local autonomy era has changed the structure of power and new 
designs on democratic institutions more open and democratic through contestation of Regional Head Election (Pemilihan Kepala Daerah/ Pilkada). Democratic capitalization and political pragmatism is increasingly fragmented political behavior of the people, the political choice of the people is increasingly not easy to localize the political choices of the politicians. The politician in various modes display the patterns of money polites and the make people lose political rationality.

The political logic of the people has been caught in the vortex of political pragmatism and has no power to avoid all that. Meanwhile, political party which is actually a symbol instrument of articulation of political aspirations becomes the cartel and practice of political mafia in the arena of Local Head Election (Pemilihan Kepala Daerah/ Pilkada). The political market has been colored by political transactional and conspiracy issues between political elites and market (capital) and educating the mentality of the people into political absurdity in the black market of democracy

In the political pragmatism, local Head Election is to be made and fomulatiorn of strategies by local actors to influence political choices of the people. One of the strategies for influencing local actors is use of capital (money politics) and patronage networks played by political elites. The high cost of democracy in local elections making political gambling behavior, that is political mafia by mobilizing economic and political resources, conspiracy, and design by local actors to gain economic and political advantage.

The politics transactional, vote buying, money politics, patronage and clientelism as discribed by some political experts like (Allan, 2012, Aspinall, 2013, Aspinall, 2014, Aspinall and As 'Ad, 2015; Aspinall and As'ad, 2016; Hutchcroft, 2013; Stokes, 2013; Choi, 2011; As'ad, 2016). Therefore, the real owner of the contest stage of Local Head Elections is to be political gambler contestation.

Political actors, do not operate individually in Local Head Elections but rather collaborate in a structured manner with other actors. All that can be effectively done because of the abundant funding support in the Local Head Elections is an instrument of selecting and giving birth to political elites or local authorities for credibility, but the Local Head Elections instead shifted the meaning of being the arena of democratic decay. The Local Head Elections requires a lot of money by political parties or candidates who fight in the elections.

Empirically, there are two modes that political actors can use in elections. First among them, there is a forward directly to the candidate. Secondly, it does not directly advance as a candidate but is a fundraiser for candidates who advance in the elections by financing all the advanced candidates so that any candidate who wins the election will not be a problem and will still benefit the political gambler. The oligarchs predatory in local Head Elections in the current democracy stage seems to form a mutualistic symbiosis system with the condition of the people who are currently experiencing economic and social slump. The world of democracy after fall Suharto's regims are tendre turn towards new authoritarianism in the pack of democracy.

The rise of the owner of the capital supporting in the Local Head Elections to invest their funds in the elections because they believe will gain an abundance when the candidates who supported it won. Political capital assistance to candidates is voluntary, but not infrequently in the form of loans or debts. For candidates who lose in elections, at risk must return the debt. Somebody had to sell the property until it was sold out. Some even experience stress until there get crazy due to debt.

The Local Head Election after political reform, actually just only represent the interest of political parties in a formalistic democratic constellation and the Local Head Elections loses substantive meaning with manipulation and conspiracy. In other side, elections are vulnerable to being used by bureaucratic elites, especially by incumbents with some modes: First, through the provision of social assistance (Bantuan Sosial) and grant funds. Second, make populist programs. Third, provide financial assistance to the regency/municipality which is the base of supporting the incumbency. Fourth, increase the salary allowance of bureaucrats or Civil Servants in the regions. Fifth, allocate for 
the development of infrastructure such as road construction. Sixth, misappropriation of village funds. Seventh, infiltrate the interests of incumbents in preparing the Budgeting Allocation for Local Developmen (Anggaran Pendapatan dan Belanja Daerah/APBD). Eighth, using funding sources of publications of local government activities covered in the activities of various agencies, especially public relations by installing advetorial or news paying the prospective incunbents in print media, electronics to online, paid at the rate per news or per month, with holding a mass media that provides space or duration for imaging or raises the popularity and electability.

In the case of Local Head Election in Barito Kuala (Batola), Hasanuddin Murad, two priods of Head Government of Barito Kuala (2007-2017) who was openly supportive of his wife, Hj Noormiliyani Aberani Sulaiman and his nephew Rahmadian Noor to be candidate of Head Governmenet (2017-2021). This information comes from journalists or media activists, especially Media Kalimantan in South Kalimantan. As a comparison of the District Government of Hulu Sungai Utara in the run-up to the 2017 elections, it has allocated publication funds for bupati-vice regent activities of $\mathrm{Rp} 10$ billion, much higher than the average, such as Hulu Sungai Selatan (HSS) 2 billion in APBD 2017.

Rather than relying on local financial resources, the emergence of a number of entrepreneurs in the political arena of Barito Kuala (Batola) at that time, democracy has been hijacked and controlled through the power of capital, state power dictated through the placement of people within the network of government bureaucracy, institutions of power, democratic institutions and political parties Gave birth to a hijacking of democratic values. The rise of tugs of interest in the political transaction has dragged of democratization into the vortex of the interests of certain elite groups. According to Hertz (2011) in his work The Silent Take over and the Dead of Democracy, where democracy has been hijacked by the power of capital

After the fall of Suharto's regime, changing of political institutions are expected to build economic and political life better, does not lead to change significant although the institution of power has changed. The political institution has changed but not changes in the behavior of political actors who still behave in pridatory oligarchy (Hadiz, 2010). Therefore, what is happening about democratization is mostly controlled by political actors. The changing of politics in democratization era is not necessarily accompanied by the fall of the power of the oligarchy.

The strength of the oligarchy has been decentralized to the local level and survived after fall of Suharto's regims in the democratization era that gave birth to the change of power institutions as an effort to end the power of oligarchy and the practice of nepotism through the presence of new institutionalism for the building of the power of new predatory oligarchs at the local level by local actors. The issue of decentralization has hijacked local capitalists and political elites to build a new oligarchy by mastering democratic institutions (legislative and political parties) or placing loyalists in government (executive) bureaucracies. The problem of democratization arises because of the existence of predatory power which became a legacy of the New Order and decentralized at the local level. The local actors has taken advantage of institutional change and patronage networks (aspinall and As'ad, 2013; 2014; Hadiz, 2010).

\section{Local Head Election of Barito Kuala (Batola) Under the Shadow of Mine and Oil Palm Plantation Entrepreneurs}

South Kalimantan is known as the region having the second largest mining resource potential in the country and has the potential of mining resources, now shifting to oil palm plantations that have surrounded 9 districts in South Kalimantan. Citing the news reported by jejakrekam.com on March 8, 2017, from the statement of the Chairman of the Indonesian Palm Oil Association South Kalimantan Totok Dewanto stated that now there are 9 districts that have transformed into a palm plantation center on an area of four hundred thousand $(400,000)$ hectares. These oil palm plantations are spread in Barito Kuala, Hulu Sungai Selatan, Hulu 
Sungai Utara, Tapin, Tanah Bumbu, Kotabaru, Balangan, Tabalong and Tanah Laut.

Well, the big players in the palm oil business is a national and international network, especially from Malaysia which mostly has mastered the area of productive land and swamp in Barito Kuala District, such as Sinar Mas Group, Astra Graha Lestari Group, Minamas Group and others. In addition, local entrepreneurs joined by Hasnur Group, Jhonlin Group and others also played, including Batola Hasanuddin Murad Regent in the palm oil business of producing cooking oil (CPO) and soap industrial raw materials and others, amid the mine business melasunya Coal due to price fluctuations from export destination countries such as China, India, Japan and others.Such a position ultimately leaves local actors no longer relying on mine potential but also targeting large-scale plantation enterprises as one of the pundi to generate multiple profits.

They are involved in local political rituals (see Pilkada), especially supporting figures or candidates for regional heads who will ensure their business networks and businesses in the area. At that time the mines power and oil palm plantations had been in the power of local oligarchy in line with the policy of decentralization and regional autonomy. The dynamics of local politics in South Kalimantan in every democratic event is always related to the issue of natural resources. The Local Head Election as a process of democratization has been captured by the power of capital through a conspiracy between the ruling candidate and the entrepreneur.

In post-election, the entrepreneurs as a regulator of the democratic stage that can regulate the pattern of attacks and rhythm of political game in South Kalimantan are practically involved. Thus, it is not surprising that post-election entrepreneurs are positioning themselves in government as shadow government and crony business local rulers who monopolize economic resources, in particular the mining business, oil palm plantations, and infrastructure development projects, as political repayment or kick back.

As well known most local government are elected in elections at behind it is a mining entrepreneur, including plantation entrepreneur. It is not surprising that the local government elected in election of the business mining are more likely to represent predatory oligarchic rulers. The implications of post-election will be the monopoly of control of local economic resources controlled by loyalists and cronies of rulers who have contributed to the electoral process. The election have been political ritual instrumental in establishing economic and political patronage for local oligarchs in some elections in South Kalimantan. The implication in post-election will be monopoly of mining control by entrepreneurs as the crony of the ruling business elected in the elections.

Involvement of entrepreneurs in elections as a supplier of funds to build patronage with local authorities who succeeded in disaggregating is in order to expand the business network while collaborating with local authorities. The involvement of a number of entrepreneurs as funders is difficult to avoid, because between entrepreneurs and potential rulers alike have an interest. It is not even possible that funders play on two legs to fund the local ruling candidates. The issue of natural resources becomes a hostage and an arena of economic and political interest struggles among local actors. It is not surprising, therefore, that the political scene in South Kalimantan is controlled by the strength of capital or dominated by politicians with mining entrepreneurs.

In the political capitalization and pragmatism era, politicians with entrepreneurial backgrounds will have opportunity win of political power through political ransactional. Therefore, only large capital owners who have a certain opportunity or person who has a patronage relationship with capital domination can appear as a fighter in the elections. Meanwhile, for people who do not have capital, although they have integrity, social capacity and political capacity, but do not have the political belief to win the struggle for political power in the arena of elections. This condition became phenomenon in political landscape in some elections in South Kalimantan.

During election, the possibility of bartering permit mining business, oil palm 
plantations, and others, without seeing the law and regulations process is very slim. The conspiracy of interests between candidates (regents, mayors, governors) in the electoral process and in post-election will ultimately have implications for elite capture corruption, rent seeking, and mining mafia including large-scale plantations.

South Kalimantan position in the global economic trend has strategic value in the mining economy and oil palm plantations. The economic activity of coal mining, including oil palm plantations, is mostly enjoyed by oligarchs, both actors who are in the center who have business networks with rulers and entrepreneurs in South Kalimantan. The activities of coal mining and oil palm plantations are not only seen in the perspective of economic activity, but also in the context of political business networks or political interests far ahead.

This patronage network was born through activities as a mining entrepreneur who became part of a successful team or funding supporter in the election process (As'ad, 2013).The electoral process is colored by political conspiracy and business networks have tend to become predatory oligarchs.As a result, political actors who play their role as financiers during the election process take place, then post elections will present themselves as a shadow political figure and businessmanager.

The involvement of a number of coal mining businessmen, including oil palm planters as political bookkeepers or as candidates for regents and governors is an interesting phenomenon in the local political scene in South Kalimantan. In the midst of post-New Order democratic market capitalization, the involvement of a number of mining entrepreneurs who become candidates for regional heads has made democracy market more open and expensive in the midst of people's political pragmatism. In the Pilkada case in some areas in South Kalimantan, the issue of Pilkada and the politicization of the mining business has become an integral political marketing in the dynamics of local politics.

The dynamics of local politics in South Kalimantan is always the network between mine activity and politics is inseparably the attraction of a breath produced by local actors. In addition, the position of political parties in South Kalimantan is more controlled by mining entrepreneurs. The political elites having a strategic position in the party will automatically have a political bargaining position in the political landscape process, especially in the elections. Coal mining entrepreneurs have made political party institutions a strategy of building economic and political power relations between local and central actors.

In theNew Order government era, Golkar Party dominated the political nationa in Indonesia. In the post-New Order regime, Golkar Party is no longer a single or dominant force in building power structures, but has been fragmented through the power of political parties in establishing political power structures at both national and local levels. Therefore, in the case of South Kalimantan, some mining entrepreneurs occupy strategic positions within the party. By controlling the party, the local oligarchy will be more structured because it has made the party as a cartel or a corporation rather than a political catalyst of the people.

Therefore, the mining entrepreneurs who have large capital and have a number of mining companies, as well as retired bureaucrats (regents and governors) who have large capital, competing for a strategic position in a political party or become chairman of one political party. By controlling the institutions of democracy will have value strategic and construct economic and political concessions for ruling candidates, both in terms of funding power and in terms of political value

The mining business network will only revolve around people who have made it into the power network and forming a business client under the protection of the powers of public officials (regions or governor) elected in the electoral process. The actors who play in the arena of the mining industry are the ones who were born as business client, shadow government, and local bossism. These actors seek to establish power relations with legislative and governmental institutions to gain policy support through the creation of a number of local regulations related to the policy of mining and oil palm plantation management. 
The actors involved in the election will eventually appear as rent-seekers. The issuing of mining permits and palm oil plantations will be easier for business clients as a form of political repayment for winning public officials in political or electoral contests. In view of the development of economic and political dynamics, particularly in relation to the existing coal mining management policy in South Kalimantan, the meaning of decentralization in the context of natural resource management does not necessarily eliminate the predatory patronage and oligarchy patterns that are inherited from the New Order, The emergence of a number of local actors in the political stage of entrepreneurial background, not just rely on social capacity, political capacity, no less important must have financial capability.

This of course can only be owned by people with entrepreneurial background and at the same time have a chance to win in the struggle for political power as in case with some areas in South Kalmiantan. As'ad research (2013) on Local Election: Mining and Local Bossism in South Kalimantan shows a number of facts about the involvement of a number of coal mining businessmen into political brokers in local elections in a number of areas in South and Central Kalimantan. The involvement of a number of mining entrepreneurs into political brokers in Pilkada in the hope of obtaining political remuneration from elected rulers in elections, particularly related to the management of regional economic resources or infrastructure development projects. Therefore, post election of various policies made by elected officials then the policy will be in favor of the interests of political patronage.

\section{Local Actor and Political Patronage Network: South Kalimantan Pilgub 2015 Affects Political Map of South Kalimantan 2017}

Understanding of local political landscape in Pilkada 2017 in Barito Kuala District is closely related to the succession of Pilkada 2015, especially in the election event of Governor-Vice Governor of South Kalimantan. In general, after the death of Chairman of South Kalimantan Golkar Party, H. Abdussamad Sulaiman HB on June 14, 2015, automatically there are only two power investors that greatly affect the map of politics in South Kalimantan. First, is the person behind the Governor of South Kalimantan H. Sahbirin Noor who is now H. Andi Syamsudin, the owner of the Jhonlin Group, although not appearing in public, but the supply of funds given to $\mathrm{H}$. Sahbirin Noor for campaign funds and money politics is very large.

Jhonlin Group who helped oversee $\mathrm{H}$. Sahbirin Noor who is now familiar with the iconic Uncle Birin in all political activities is now famous. $\mathrm{H}$. Isam's competitors come from Binuang sub-district of H. M. Hatta alias H. Ciut and $\mathrm{H}$. Zaini Mahdi alias $\mathrm{H}$. Izai who are big mining entrepreneurs in Tapin Regency and most influential under the banner of P. T. Batu Gunung Mulia (BGM). They are behind the financial strength as well as the network in the exploitation of former Mayor of Banjarmasin $\mathrm{H}$. Muhidin together with former senator of DPD RI, Gusti Farid Hasan Aman as candidate for Governor-Vice Governor of South Kalimantan period 2016-2021. The rest, small coal entrepreneurs like H. Jahrian Noor, H. Amir, H. Parlin which is the miners and coal cukong with the concession area are in Tanah Laut Regency and part of Tanah Bumbu Regency.

The Golkar Party of South Kalimantan in the era of leadership H. Leman has been predicted to support the former Regent of Banjar, Gusti Khairul Saleh as a candidate for Governor of South Kalimantan with a capital of 13 seats is actually only Golkar Party capable of independently carrying their own candidates, without having to berkoalisi with other political parties. Therefore, the requirements set for the political parties in the Law on Regional Head Election applied in 2015 elections in conjunction with only 20 percent of the total seats in the DPRD. This means, of the 55 seats available, with 13 seats Golkar Party has exceeded the minimum limit of only 11 seats.

By the death of H. Leman, it turns out in the seconds of registration of candidates for Governor-Vice Governor of South Kalimantan, Golkar Party prefer H. Sahbirin Noor to Gusti Khairul Saleh. In terms of a board and entrepreneurs Banjarmasin incorporated in Golkar Party of South Kalimantan, Irwan 
Gunadi (a network of tycoon business Anton Gunadi in Banjarmasin) said that the exploitation of H. Sahbirin Noor is a coalition of snapper as a result of three big businessmen who are mentioned as the funders of $\mathrm{H}$. Isam with Jhonlin Group, Anton Gunadi with Bina Banua Group conglomerate who triumphed in the world of timber, rental of heavy equipment, and hotel business in Banjarmasin and the last is the owner of Hasnur Group, H. Leman.

Even so, hadangan want to do Gusti Iskandar Sukma Alamsyah (Chairman of DPD Golkar Party of South Kalimantan vice Agung Laksono), after there are 7 political parties who pushed H. Sahbirin Noor with the capital strength of the big coalition. Because, the Golkar Party version of Aburizal Bakrie, chaired by $\mathrm{H}$. Leman and subsequently replaced by his son, Hasnuryadi Sulaiman (member of Parliament), United Development Party version of Romahurmuziy (because PPP Djan Faridz version commanded by DPDRI member HM Sofwat Hadi instead chose H. Muhidin-Gusti Hasan Farid), Gerindra Party, Prosperous Justice Party, National Mandate Party and Hanura Party.

As a result of political parties which have pushed H. Sahbirin Noor who chose Rudy Resnawan who previously served as Vice Governor of South Kalimantan as a companion, automatically made Golkar power to be in the hands of Uncle Birin. Hence, Gusti Iskandar Sukma Alamsyah who want to advance through Golkar, finally stuck when enrolled with academics FKIP University Lambung Mangkurat (ULM) Banjarmasin, DR Karyono Ibn Ahmad with support from the DPP Golkar Party version of Agung Laksono. Until finally, the South Kalimantan Election Commission decided not to accommodate the Golkar Party and PPP support letters are stated double.

From here, the beginning of the change of political map in South Kalimantan that affects the next democratic party in 2017, especially in Barito Kuala (Batola) and Hulu Sungai Utara (HSU). It was stipulated by Election Commision of South Kalimantan that H. Sahbirin Noor and Rudy Resnawan as Governor-Vice Governor of South Kalimantan period 2016-2021 with voice reaching 739,588 or 41,09 percent, followed by independent candidate $\mathrm{H}$ Muhidin-Gusti Hasan Farid with 725,585 votes or 40,31 percent and Zairullah Azhar-Muhammad Safi who carried PKB, Party Nasdem, and the Democratic Party is only 334,712 votes or 18.6 percent.

According to Arief (Barito Post journalist, interview on February 15, 2017), the reason why H. Muhidin did not file a lawsuit with only 1 percent permitted by the Constitutional Cour in Jakarta was because there is a business political deal that binds between H. Muhidin and H. Isam (owner of Jhonlin Group) for coal transport cooperation through a special port owned by $\mathrm{H}$. Muhidin. Not only business agreements, criminal cases that ensnare $\mathrm{H}$. Muhidin handled Police Headquarters can be dismantled again, if the former mayor of Banjarmasin is still desperate to file a dispute election 2015 to the Constitutional Court in Jakarta.

Meanwhile, Group Binuang-the name for the group $\mathrm{H}$. Izai and $\mathrm{H}$. Ciut who had been a political partner and financiers $H$. Muhidin released, because of the attachment of $\mathrm{H}$. Muhidin with Jhonlin Group. Not surprisingly, if the group of $\mathrm{H}$. Izai and $\mathrm{H}$. Ciut who had previously been opposed to $\mathrm{H}$. Muhidin, to hijrah from Binuang to Banjarmasin, who then led DPW Reform Star Party (PBR) South Kalimantan, triggered business problems and unfair friendship relationship.

From this information Arief mentioned if $\mathrm{H}$ Ciut could collect money that has been used H. Muhidin for campaign funds and for-money, which was then replaced by $H$. Isam as a political compensation for not suing the results of South Kalimantan Election 2015 to the Constitutional Court. The attachment of $\mathrm{H}$. Muhidin with $\mathrm{H}$ Isam was proven, during the National Mandate Party (PAN) on Tuesday (15/3/2016), at G'Sign Hotel Banjarmasin which is one of the luxury hotels in the capital of South Kalimantan Province, whose information all costs are borne $\mathrm{H}$. Isam. Including, Jhonlin Group private jet pick up to luxury cars provided to DPP PAN Chairman, Zulkifli Halim.

To strengthen the influence of Jhonlin Group, H. Isam was appointed as Chairman of the Advisory Council of DPW PAN Kalsel, in addition Jhonlin Group employee, Zaiful Aswad was placed as Bendara DPW PAN Kalsel. 
Automatically, PAN entered from the power network of Jhonlin Group under the control of H. Isam.Then what about Golkar? Although once seized Gusti Iskandar Sukma Alamsyah after 'coup' Hasnuryadi Sulaiman as Plt Chairman of DPD Golkar Party of South Kalimantan, was the name of H. Sahbirin Noor a Governor of South Kalimantan became the main choice. Gusti Iskandar who is also the board of DPP Golkar Party was finally eliminated in the Extraordinary Regional Meeting (Musdalub) Golkar South Kalimantan held at the office of DPP Golkar Party in Jakarta on March 31, 2017.

All this is inseparable from the role of politicians who had been eliminated when Gusti Iskandar Sukma Alamsyah led Golkar, such as Murhan Effendie (Chairman of Golkar faction of South Kalimantan DPRD and Secretary of DPD Golkar Party of South Kalimantan), H. Supian H. K (businessman known close to H. Sahbirin Noor), Noor Aidi (former Regent of Tabalong and expert staff of South Kalimantan Governor), and of course the support of Setya Novanto (DPP Chairman of the Golkar Party) is not a public secret close to Jhonlin Group's business and political network.

Therefore, the political partnership played by Barito Kuala Regent (Batola) Hasanuddin Murad to smooth his wife, $\mathrm{Hj}$ Noormiliyani Aberani Sulaiman and his niece, Rahmadian Noor as candidates for Regent Batola period 2017-2022 period, not disturbed by political gonjing in the body of Golkar Party. Hasanuddin Murad's political deal with Gusti Iskandar Sukma Alamsyah who is both Golkar and Golkar politics together with former members of the House of Representatives, can actually wake up when Uncle Birin leads Golkar.Then what about Zairullah Azhar?

Post-defeat in South Kalimantan Election 2017, Chairman of DPW PKB is indeed more concentrated to the world of education with many have an educational foundation that oversees the STIENAS Banjarmasin, AKPARNAS, STIMIK Banjarmasin, AKBID Borneo and other flowers. However, Zairullah Azhar remains consistent in choosing a path beyond the power of the Jhonlin Group that has been rooted in Golkar, PPP, PAN, PKS and PDI Perjuangan during the 2017 Batola elections.
Zairullah Azhar's version is a must-balance force in the midst of oligarchic dominance of mining entrepreneurs who have touched Political life line of South Kalimantan.

Zairullah Azhar always maintains good relations with Guntur Prawira, a mass media entrepreneur (owner of Barito Post daily) and contractor who is also Chairman of DPW Democratic National Party (Nasdem) South Kalimantan, post elections 2015 and continues to elections in 2017 in Batola and Hulu Sungai Utara HSU). This is evidenced by the appointment of $\mathrm{H}$. Jahrian Noor directly from the result of lobbying between Zairullah Azhar and Guntur Prawira being the Chairman of DPD Nasdem Party of Barito Kuala Regency (Batola), without having to go through regional deliberation mechanism or the like.

Meanwhile, after the elections of 2015, $\mathrm{H}$. Muhidin who has tied political and business contracts with $\mathrm{H}$. Isam, must be obedient and run it. This was acknowledged by Vice Chairman of DPW PAN South Kalimantan, Djumadri Masrun (interview on Friday, August 12 , 2016) that all party guidelines under the leadership of $\mathrm{H}$. Muhidin should be consulted with $\mathrm{H}$. Isam. When determining between carrying Hasan Ismail (Chairman KNPI South Kalimantan and Head of Gunung Makmur, Tanah Laut Regency) with H. Bahrian Noor (Vice Chairman of DPC PKB Tanah Bumbu which is the younger sister of H. Jahrian Noor, coal mining businessman). Considering $\mathrm{H}$. Muhidin because behind Hasan Ismail there is Regent of Tanah Laut, Bambang Alamsyah and Regent of Tanah Bumbu, Mardani H. Maming who is also Chairman of DPD Democratic Party of Struggle Indonesia (PDIP) South Kalimantan

This is because before offering Hasan Ismail, Mardani H. Maming and Bambang Alamsyah first came to $\mathrm{H}$. Adriansyah (former member of House of Representatives from FPDIP who was caught in bribery case in PDIP Congress in Bali) in Lapasa Suka Miskin, West Java. The reason that made Hasan Ismail appear was because the Jhonlin Group presented politically South Kalimantan Governor $\mathrm{H}$. Sahbirin Noor who once conducted trial and error, by putting his surname, H. Ahmad Subakti again using a similar icon, Uncle Nanang before 
the registration stages of the candidates of Regent Batola Period 2017-2022. Apparently, the public response to Uncle Nanang who is only a junior high school teacher in Marabahan is not strong financially to support ed Uncle Birin during the South Kalimantan Regional Head Election in 2015.

Not surprising, if finally the Great Coalition which was done by Uncle Birin in the election of Governor-Deputy Governor of South Kalimantan 2015 was imitated Hasan Ismail with the same pattern plans to break the vote of Golkar, by holding Fahrin Nizar (Batola member from Golkar emerges. So, in broad outline, Jhonlin Group did not play very much in Batola with its oligarchic network. It is precisely Binuang Group led by H. Izai and H. Ciut who became opposing $\mathrm{H}$. Isam in the political arena in South Kalimantan, also played behind the scenes H. Bahrian Noor-H. Suwandi. Therefore, the Binuang Group has the interests of the port business of fuel oil (BBM) as well as the existing sand mines on the coast of the Barito River, near the Barito Bridge area.

Although not too obvious, Binuang Group network is a political enemy Hasnur Group is also targeting palm oil plantation in Batola. The political actualization played by $\mathrm{H}$. Izai and $\mathrm{H}$. Ciut in Batola, can be seen clearly from the movement played by members of the House of Representatives from Golkar Party, Bambang Heri Purnama in every recess or down to the public in absorbing aspirations, promoted $\mathrm{H}$. Bahrian Noor. Meanwhile, Zairullah Azhar also melakoni similar things, with the pattern from the mosque to the mosque, or one pengajian to other pengajian.

Well, the political actors in South Kalimantan have split into two major forces namely H. Sahbirin Noor and H. Muhidin, Mardani H. Maming who became the representative of Jhonlin Group with his 'grand master', H. Isam behind the power of Hasan Ismail-Fahrin Nizar. Then, the political resistance that Zairullah Azhar-Guntur Prawira and Binuang Group-though not too prominentpresented for the victory of $\mathrm{H}$. Bahrian Noor-H. Suwandi in elections 2017. Meanwhile, Hasanuddin Murad (Regent Batola) with bureaucratic and ethnic networks Dayak
Bakumpai plus Banjar Pahuluan, also played a role to win the Noormiliyani Aberani SulaimanRahmadian Noor.

\section{Local Head Election of Barito Kuala Regency: Arena for Political Effect of Local Actors}

The couple of Noormiliyani-Rahmadian Noor excel with 48.11 percent voice managed to surpass her rivals in the elections namely Hasan Ismail-Fahrin Nizar (34.61 percent) and Bahrian Noor-Suwandi (17.28 percent). Regent elected Noormiliyani paired with Rahmadian Noor is the wife of Hasanuddin Murad who has served as Regent Batola two periods. While Ramadian Noor as Vice Regent elected none other than Hasanuddin Murad's nephew. The appearance of Normiliyani-Rahmadian Noor as the winner in the Barito Kuala election has allowed the politics of the dynasty of Hasanuddin Murad's ethnic group on the local political scene in Barito Kuala.

The Normaliyani-Rahmadian Noor pair promoted by the Golkar and Democrat parties, the Bahrianoor-Suwandi couple were supported by the National Awakening Party and Gerindra Party, while the Hasan Ismail-Fahrin Nizar pair was supported by the Prosperous Justice Party, Partai Amanat Nasional (PAN), Partai Unity of Development, Indonesian Democratic Party of Struggle, Hanura Party, and Crescent Star Party

When observed by the Chairman of the Political Party, the bearers of couples candidate are persons with entrepreneurial background, local officials, or former local officials. Like Golkar Party as a bearer of the couple Normaliyani-Rahmadian Noor, one of the important members of the Golkar Party is Hasanuddin Murad who carried his wife as a candidate for Regent Barito Kuala. PKB and Gerindra Party carrying the couple BahrianoorSuwandi as it is known that the Chairman of the PKB South Kalimantan Zahirullah Azhar former Regent Tanah Bumbu two periods that have a network with the mining entrepreneurs, while Chairman of the Gerindra Party of South Kalimantan is H. Abidin who is known as an entrepreneur or owner Port of coal mine.

Meanwhile, the support of political parties for the couple Hasan Ismail-Fahrin Nizar, in the 
Indonesian Democratic Party of Struggle for the Regional Leadership of South Kalimantan is Mardani H. Maming who still serves as Regent of Tanah Bumbu two periods, National Mandate Party (PAN), Chairman of South Kalimantan Muhidin (former Mayor of Banjarmasin, with a background of mining entrepreneur), United Development Party (PPP), its central figure is Rudy Ariffin (former governor of South Kalimantan), although operatively run by his son, member of Commission II of DPR RI from FPPP, HM Aditya Mufti Ariffin.

The three candidate fighting in Barito Kuala election each behind him are the people or the oligarchs with the background of businessmen, local officials, or former rulers who have networks with mining entrepreneurs. Hasanuddin Murad as Regent Barito kuala two periods have managed to deliver his wife as the winner. In the process of socialization or campaign periods of mass mobilization are very clear and massive structure at all points of the location ranging from remote villages to the subdistrict level with the direction of the land and river transportation fleet.

Mass mobilization at the time of the campaign as an arena of strength performances difficult to see by other candidates. The Golkar Party that is in charge of the local political universe in Barito Kuala District is certain that the more solitary network of organizations and added by the funding support of the Golkar Party elites that owns the mining business network has become an unmoved force during the campaign period. Not only that, funding support for the couple Normaliyani-Rahmadian Noor came from local businessmen (Barito Kuala). A local entrepreneur who is engaged in a renowned contractor named $\mathrm{H}$. Inab.

According to the Leadership Ethnicity Bakumpai, Mr. Budiman, that $\mathrm{H}$. Inab has provided funding of Rp 5 billion for the couple Normaliyani-Rahmadian Noor in Pilkada. Understandably, during this network of infrastructure projects such as roads, bridges, markets and others controlled H. Inab group and includes Rahmadian Noor with a background of local contractors. Because, in the ranks of the bureaucracy, especially in the Public Works
Agency Batola and wetlands filled with people Hasanuddin Murad.

Meanwhile, the Bahrianoor-Suwandi couples carried by the National Awakening Party (PKB) and Gerindra Party can not do much in political gambling. Chairman of the Gerindra Party of South Kalimantan, H. Abidin, who was originally expected to provide funding support is not exactly what the couple expected. In fact, according to information circulated and reinforced by a number of respondents, for example Abdul Sani (NGO activist and tansmigrant resident organization from Java Island) explained that at the time of open campaign and public applying Prabowo Subianti's presence was not present and without confirmation about the absence of the Chairman of the Grindra Party.

Similarly, H. Abidin as Chairman of the Gerindra Kalsel Party also did not attend during the open campaign and according to information left for Germany. According to Abdus Sani, there is a political concession between the number one couple, Normiliyani-Rahmadian Noor that $\mathrm{H}$. Abidin does not need to be active to win the second pair of Bahrianoor-Suwandi by accepting a two-billion-dollar compilation as a silent fund. The key figure behind BahrianoorSuwandi's nomination is H. Jahrian Noor.

As a former religious teacher, H. Jahrian is one of the most successful coal mining businessmen in South Kalimantan and also as Bahrianoor sibling. Apparently, as recognized by the Bahrianoor success team, Annisa said that the pair number two was lost because the elite party that supporters only halfhearted and not maximally let alone provide political aid. A. H. Jahrian is not enough to fight democratic predators who each rely on the power of money in the elections.

The couple candidate of Bahrian-Suwandi loses money and not many entrepreneurs provide support to the candidate so that the losses are lost and the community is already patterned with money politics. Why this happened? Therefore, since Thursday (January 26, 2017), hauling (special road) PT Talenta Bumi including mining business owned by $\mathrm{H}$. Jahrian closed the Integrated Team Enforcement of Local Regulation No. 3 of 2012 on Special 
Road of Coal and Oil Plantation which is a combination of Transportation Department, Communication and Information South Kalimantan together with Directorate of Traffic Polda South Kalimantan, plus assistance from Korem 101/Antasari. Also attended was hauling owned by PT Binuang Mitra Bersama (H. Izai and $H$. Ciut's business network) and Hasnur Group for 41 days with estimated loss of Rp 41 billion.

This is also explained by the Chairman of the Association of Mining Society (Permata) of the People of Kalimantan, Syamsul Daulah (interview on Thursday, January 26, 2017) that due to the closing of hauling to three local companies owned by $\mathrm{H}$. Jahrian, H. Izai and Hasnur Group is coal transportation activities ranging from 500 to 1,000 Ton per day by South Kalimantan Governor H. Sahbirin Noor who issued letter number 551/97, dated January 23, 2017 to South Kalimantan Police Chief Brig. Gen. Erwin Triwanto to cover the existing hauling as it was considered violated by law No. $3 / 2012$, and followed up a letter from the Ministry of Public Works And Spatial Planning (PUPR) of the Directorate General of Highways, National Road Implementing Agency XI Number 02.06-Bz / 027, concerning the obligations of the mining entrepreneurs to create a flyover in the national road area connecting Marabahan-Margasari to the coal-specific port area in Sungai Puting, Kabupaten Tapin.

The couple candidate of $\mathrm{H}$. BahrianSuwandi loses money and not many entrepreneurs provide support to the candidate so that the losses are lost and the community is already patterned with money politics. Why this happened? Therefore, since Thursday (January 26, 2017), hauling (special road) PT Talenta Bumi including mining business owned by $\mathrm{H}$. Jahrian closed the Integrated Team Enforcement of Local Regulation No. 3 of 2012 on Special Road of Coal and Oil Plantation which is a combination of Transportation Department, Communication and Information South Kalimantan together with Directorate of Traffic Polda South Kalimantan, plus assistance from Korem 101 / Antasari. Also attended was hauling owned by PT Binuang Mitra Bersama (H. Izai and H. Ciut's business network) and
Hasnur Group for 41 days with estimated loss of Rp 41 billion. This is also explained by the Chairman of the Association of Mining Society (Permata) of the People of Kalimantan, Syamsul Daulah (interview on Thursday, January 26, 2017).

That due to the closing of hauling to three local companies owned by $\mathrm{H}$. Jahrian, H. Izai and Hasnur Group in coal transportation activities ranging from 500 to 1,000 Ton per day by South Kalimantan Governor H Sahbirin Noor who issued letter number 551/97, dated January 23, 2017 to South Kalimantan Police Chief Brig. Gen. Erwin Triwanto to cover the existing hauling as it was considered violated Bylaw No. $3 / 2012$, and followed up a letter from the Ministry of Public Works And Spatial Planning (PUPR) of the Directorate General of Highways, National Road Implementing Agency XI Number 02.06-Bz / 027, concerning the obligations of the mining entrepreneurs to create a flyover in the national road area connecting Marabahan-Margasari to the coal-specific port area in Sungai Puting, Kabupaten Tapin.

Similarly, H. Abidin as Chairman of the Gerindra Kalsel Party also did not attend during the open campaign and according to information left for Germany. According to Abdus Sani, there is a political concession between the number one couple, Normiliyani-Rahmadian Noor that $\mathrm{H}$ Abidin does not need to be active to win the 2nd pair of Bahrianoor-Suwandi by accepting a two-billion-dollar compilation as a silent fund. The key figure behind BahrianoorSuwandi's nomination is H. Jahrian Noor. As a 'former' religious teacher, $\mathrm{H}$. Jahrian is one of the most successful coal mining businessmen in South Kalimantan and also as Bahrianoor sibling. Apparently, as recognized by the Bahrianoor success team, Annisa said that the pair number two was lost because the elite party that supporters only halfhearted and not maximally let alone provide political aid. A. H. Jahrian is not enough to fight democratic predators who each rely on the power of money in the elections.

From the explanation Syamsul Daulah explains ultimately due to the closure hauling the supply of funds for the couple H. Bahrian Noor-H Suwandi who plans to win the 
candidates Regent Batola Regent was limited, because the source of money from the special road and special port owned H. Jahrian Noor closed apparatus Law enforcers at the request of the Governor of South Kalimantan H. Sahbirin Noor became blocked ahead of polling day on Wednesday, February 15, 2017. It is also recognized Aspihani Idris (activist Legal Aid Institute) make bargaining Hasnur Group originally wanted to be directed to support Hasan Ismail-H. Fahrian Noor through one of its members, H. Yuni Abdi Nur Sulaiman (Chairman of the Family Harmony Bakumpai Pusat) became weak. Similarly, H. Izai with Group Binuangnya also helpless. This also makes the political deal between Sahbirin Noor to win the chair of DPD Golkar Party of South Kalimantan in Musdalub IV in DPP Golkar Party in Jakarta, became smooth because of the strength of capital and network of law enforcement apparatus controlled by $\mathrm{H}$. Isam, owner of Jhonlin Group.

From here, the political deal between $\mathrm{H}$. Sahbirin Noor and the Batola Hasanuddin Murad regent became stronger, with political and legal pressure demonstrated when it was able to suppress the powers of H. Jahrian Noor and Binuang, including Hasnur Group which has a strong roots with the Golkar Party. Meanwhile, the presence of Zahirullah Azhar and some people imported from Jakarta, such as artists and ustaz, Habaib to boost the constituent's voice was also not able to provide resistance in contestation Pilkada. The Hasan Ismail-Fahrin Nizar couples carried by six Political Parties also can not win elections.

Actually, this couple many hopes against Mardani H. Maming as Chairman of PDIP South Kalimantan to provide maximum funding assistance but until the time before voting no more financial aid. Funding assistance is only obtained during the nomination process of getting a grant of Rp 2 billion. Meanwhile, $\mathrm{H}$. Muhidin as Chairman of DPW PAN South Kalimantan not maximal or simply provide a political vehicle without providing funding assistance in the elections process. According to information circulating precisely PAN as the party bearers get funds from the partner Hasan Ismail-Fahrin Nizar for $\mathrm{Rp} 600$ million.
Similarly, the Social Welfare Party earns a political dowry of $\mathrm{Rp} 1.5$ billion after the Bahrianoor pair is only able to offer political dowry Rp 1.2 billion.

Thus, Barito Kuala Regency is a socioeconomic political area that is ranked 12th out of 13 districts in South Kalimantan as lagging areas compared to other regions. Barito Kuala District has no reliable natural resources as well as several other districts with potential coal mines. Nevertheless, the district is developing a palm oil plantation economy and some foreign investors mainly from China are investing in oil palm plantations. Barito Kuala District is a potential agricultural base in South Kalimantan. Approximately 48 percent of the population is transmigration from Java, a transmigration project of the New Order regime in the early 1980 s.

Barito Kuala District has even been made a pilot project of national transmigration by the central government. In the elections of 2017, the Bahrianoor couple took Suwandi as Vice Bupati's couple to accommodate Javanese transmigration ethnic community but election in Barito Kuala the issue of ethnic identity did not give significant influence and the fact was lost late. This is also felt by some extras such as former Head of Education Office of Barito Kuala District, H. Paujan Husaini who claimed to have support from Javanese Transmigrant residents and Banjar Hulu Sungai ethnic, was closed due to the game of political actors in South Kalimantan who are entrenched and entrenched and netted by the same interests Business and political networks.

Barito Kuala election is actually a battle of oligarchs to control political and economic territories. As mentioned before, although this area does not have a coal mine but this walayah is a traffic place for coal barges that cross the Barito River which is included in the territory of Barito Kuala Regency. Call it for example, Barito River source of economic income from coal barge crossings at any time but never get clear how much revenue generated from barges that pass through Barito River Flow from the royalty sector or other income sectors. When confirmed from a number of local officials on royalty or other concerns from Barito River's 
economic activity, almost all of them are silent and unable to explain clearly.

During the election process, the negative issues circulating among the people that the Batola Hasanuddin Murad district received funds from the national mining company PT Adaro Indonesia owned by Boy Tohir cs group, a coal mining company operating in Tabalong and Balangan districts, as well as several districts In Central Kalimantan Province. Transportation activities from this mine production cross the Barito River Flow. Therefore, during the election process, the Bupati of Hasanuddin Murad received Rp 15 billion as a royalty fund. In the midst of the oblique issue, the Bupati gathered the village chiefs of Barito Kuala District to clarify the issue of Rp15 billion.

\section{Where are the Positions of $\mathbf{H}$. Sahbirin Noor (Governor of South Kalimantan) and H Andi Syamsuddin in Barito Kuala Elections?}

At first H. Sahbirin Noor gave support to the couple candidate, Hasan Ismali-Fahrin Nizar before Sahbirin Noor was elected by acclamation to become Chairman of Golkar Party of South Kalimantan. Over the course of time in the elections there seems to be a signal from the Central Golkar Party Leaders to shut up. That is, take it silent so as not pro active or involved directly support the partner Hasan Ismail-Fahrin Nizar. Must do the backs of the cats supporting the number one pair Normaliyani-Rahmadian Noor who was promoted by Golkar Party H. Sahbirin Noor who has been elected as the Chairman of Golkar Party of South Kalimantan, should give support and win the number one pair $\mathrm{Hj}$ Noormiliyani AS-Rahmadian Noor.

This political situation is very detrimental to the political mate of the number three, Hasan Ismail-Fahrin Nizar who had hoped for $H$. Sahbirin Noor to support the victory in Pilkada. Pada future scenario, has been circulating political calculations in which in the next period, H. Sahbirin Noor will appear again Nominated himself as South Kalimantan Governor for the second time by holding Mardani H. Maming as a candidate for Vice Governor where Mardani H. Maming is currently the Regent of Tanah
Bumbu and Chair of PDIP of South Kaliumantan. Barito Kuala elections have become the arena of political calculation of local political elites to measure their power, loyalty, and at the same time build political concessions of local actors or local oligarchs.

$\mathrm{H}$. Syamsuddin or known H. Isam in Barito Kuala election is also barely audible. In the case as always in some elections in South Kalimantan always appear as supporters or supporters of funds or set political calculations for candidates who supported. As is known, $\mathrm{H}$. Isam currently as PAN Council Advisory South Kalimantan and Chairman of DPW PAN South Kalimantan is Muhidin former Mayor of Banjarmasin and former political rival $\mathrm{H}$. Sahbirin Noor in South Kalimantan Governor Election. H Isam is the nephew of $\mathrm{H}$. Sahbirin Noor as the main supporter of political funds in the elections of South Kalimantan Governor since 2015.

Barito Kuala election is like a proxy war of local actors to dominate political and economic territory. For political design in the future the actors always try to keep some territory to make the ruler in the region through the support line of Political Party. By placing people from politically-led parties it will make it easier to build political and economic concessions. The involvement of mine actors behind the Pilkada capitalization, as a political broker or supporting financier, and a strategy for building power relations or patronage with a potential ruler of the region.

The capitalization of Local Head Electons as process democracy in the local political landscape in South Kalimantan, especially in Barito Kuala, the issue of natural resource management always color political marketing among actors involved in power struggle. The phenomenon of mining entrepreneur involvement behind the capitalization of Pilkada becomes the arena of conspiracy and economic patronage. Most local rulers are elected in elections behind a mining entrepreneur or the ruler of that area backed by mining entrepreneurs and supported by fund from mine operators with mine business connections.

This is the fact designed by local capitalist groups, not even close possibly also 
get funding support from capitalist in Jakarta. Therefore, capitalization and political pragmatism have led Citizens into the game politics (money politics) or buying and selling votes (vote buying) that actors play in Pilkada to influence the people. Do not be surprised if Pilkada gave birth to local rulers berwatak Predatory oligarchs amid issues of democratization (Didi Gunawan, Journalist, Interview, 6 Peberuari in Banjarmasin, 2017).

"The election arena has been a rational choice for local actors as actualization of business and political networks. The implications of post-election will be there in a monopoly on the control of the mine by entrepreneurs as cronies of local ruling businesses, as explained by Muhammad Hasan (58 years old, Former Chairman of KNPI South Kalimantan, 5 Peberuari interview in Barito Kuala).

The same thing was also stated by Muhammad Effendi (60 years old) lecturer at Law Faculty of Universitas Lambung Mangkurat (Unlam) Banjarmasin, that: "The capitalization and political pragmatism in the process of democracy post-New Order, the involvement of a number of entrepreneurs as persons funds as a difficult thing to avoid, because between entrepreneurs and candidates rulers alike have an interest. It's a fact that happened all along, where the mine issue behind Pilkada has always surfaced as a deep reality landscape politics in South Kalimantan. This is the business and political network that gave birth to a conspiracy and patronage built up in a relation power among local actors", (Interview, December 2017 in Banjarmasin).

The power relations will give birth to a business cartel which is predatory, where the local economic resources are only on Groups of such predatory oligarchs ". "The mine has become part of the arena of economic and political interest struggles among local actors. Therefore it is not surprising that the political scene in South Kalimantan is controlled by force Capital or dominated politicians with entrepreneurial background mine. Amidst the capitalization and political pragmatism, the politicians who Entrepreneurial background or capital owners, will have great opportunities to win political power struggles through political and transactional concessions. Not strange if the mining resources Become hostage and dominated by local oligarchs as instruments Conspiracy of interests ", as stated by local political observer Setia Budi (Interview, 11 Peberuari 2017 in Banjarmasin).

\section{CONCLUSION}

Since the death of one of the central political and business leaders in South Kalimantan, H. Leman, automatically only two forces affect the political map in South Kalimantan. That is, the financial strength and support of government that is now controlled by H. Isam (Jhonlin Group), although on the one hand must be opposed with silent movement or openly from Binuang Group with the main actor, H. Izai and H. Ciut. However, when H. Isam was able to gain political and governmental means proven by the control of South Kalimantan Provincial Government held by $\mathrm{H}$. Sahbirin Noor, including political party networks such as PDI Perjuangan, PAN, Golkar Party, PKS, and Hanura Party and others. H. Isam has incarnated and took the position left by H. Leman, after his death.

With that position, H. Isam has also built a strong and influential political network in almost all major political parties. Although Rudy Ariffin, a former governor of South Kalimantan, is able to control the United Development Party (PPP), but essentially debt service or politics to the success of the child, HM Aditya Mufti Ariffin during legislative elections 2014. This further indicates the dominance of the main actors in business and political networks in South Kalimantan is still held by $\mathrm{H}$. Isam. Meanwhile, the concentration of $\mathrm{H}$. Izai and $\mathrm{H}$. Ciut is only in the local level, especially Tapin regency which is ahead of the succession in 2018, after being pressed by Jhonlin Group with power and law networks supported by Police and Military

The phenomenon that occurred in the 2017 Batola Election has shown that financial power, business and political networks including law enforcement officers controlled by $\mathrm{H}$. Isam 
with a leading figure who appeared to the public, South Kalimantan Governor H. Sahbirin Noor has become the actor of determining the way of political direction in South Kalimantan. Although not appearing publicly, H. Isam hands still gripped strongly in politics and business in South Kalimantan. Whether later in elections in 2018 which will take place in four districts of Tanah Laut Regency, Tabalong Regency, Tapin Regency and Hulu Sungai Selatan Regency (HSS). Even so, out of the four regions that will hold elections of Regent's Regents in 2018, Tanah Laut District will be an exciting battle, and the patterns applied in the 2017 Regional Elections can be repeated again.

\section{REFERENCES}

Allan, N. W. (2012). Diversity, Patronage and Parties and Party System Change in Indonesia. (PhD) dissertation, University of British Columbia.

Aspinall, E. (2014). When brokers betray: Social networks adn electoral politics in Indonesia. Critical Asian Studies 46 (4): 545-570.

Aspinall and As'ad (2015). The Patronase Patchwork:Village Brokerage Networks and the Power of the State in an Indonesian Election. Bijdragen Tot De Taal, Land-EN Volkenkunde 171 (165-195.

Aspinall and As'ad (2016). Understanding Family Politics: Success and Failures of Political Dynasties in Regioanal Indonesia. South East Asia Research, 1-16, SAGE.

Choi, Nankyung (2014). Local Politics Elites in Indonesia: Risers and Holdovers. Sojourn Journal of Social Issues in Southeast Asia, 292:364-407.

Hadiz, V. R. (2010). Localising Power in PostAuthoritarian Indonesaia: A Southeast Asia Perspective. Stanford, CA: Stanford University Press.

Hicken, Allen (2011). Clientelism. Annual Review of Political Science 14:289-310.
Hidayat, S. (2007). Shadow State? Business and Politics in the Province Banteng, In Schulte Nordholt $\mathrm{H}$ and Van Klinken G (eds) Renegotiating Boundaries: Local Politics in Post-Suharto Indonesia. Leiden; KITLV Press, pp, 203-224.

Hutchcroft, P. D. (2013). Linking Capital and Countryside: Patronage and Clintelis in Japang, Thailand, adn Philippines; in: D.A. Brun and I. Diamond (eds), Clentelism, Social Policies, and the Quality of Democracy, pp,. 174-2013 Baltimore: Johns Hopkins University Press.

Stokes, Susan C., Thad Dunning, Marcelo Nazareno, and Valeria Brusco (2013). Brokers, Voters, and Clientelism: The Puzzle of Distributive Politics. Cambridge: Cambridge University Press.

Susanto, (2007) Ruler, Entrepreneur and Local Government Implementation Post Regional Head Election: Case of South Kalimantan Province; In: S. Hidayat (ed.), Business and Politics at the Local Level: Entrepreneur, Ruler and Government Administration Post Post Election, pp. 183-233. Jakarta: Indonesian Institute of Sciences. 